\title{
THE PRESENT STATUS OF SUSTAINABILITY CONCEPT IMPLEMENTATION BY BUSINESSES IN SELECTED INDUSTRIES IN THE SLOVAK REPUBLIC
}

\author{
Viera Marková, Petra Lesníková, Alena Kaščáková, \\ Miroslava Vinczeová
}

\section{Introduction}

The significance of the business sustainability concept has been increasing not only abroad where it has been pursued by professionals as well as the general public for a longer time, but also here in Slovakia. It has evolved from the understood universal concept of sustainable development centred on bringing solutions to global problems and issues. It is mainly concerned with the use of limited natural resources, environmental exploitation, a fight against poverty, society polarization, etc. In a more comprehensive understanding, it involves the change and replacement of current production and consumption models with future, more sustainable ones. Looking at the complex and sectional issues of sustainable development, a positive relationship with the business sector can be observed.

With respect to behaviour of businesses, it is not only important to find practices that are not damaging to the environment, they also need to consider the economic and social areas to business as well. The concept of business sustainability implies more than an understanding of the responsibility for activities regarding the internal or external environment. Businesses that are managed in accordance with sustainability practices do not take the short-sighted view of mere survival or just maintaining the status quo. They also focus on the economic, environmental, social dimension as well as on the potential use of synergistic effects resulting from its practical long-term use with planning and implementation.

The aim of the paper is, based on the analysis of sustainability concept implementation by businesses in selected industries, to identify their underlying motives and barriers in practice. We address issues of motives that could lead to its implementation by comparing local practices to foreign research. We also attempt to identify the most frequently used tools supporting business sustainability in particular areas and as a whole. By means of a hierarchical cluster analysis, a conclusion is drawn regarding the viewed businesses' approach towards a sustainability concept.

\section{The Theoretical Starting Points of the Business Sustainability Concept}

Origins of sustainable development concepts date back to the 1970's. A general definition of sustainable development can be traced back to the United Nations (the UN), specifically to the report of the UN World Commission on Environment and Development. According to this report (Our Common Future, 1987) "sustainable development is the development that meets the needs of the present without compromising the ability of future generations to meet their own needs". Furthermore, it states, "sustainable development is a process of change in which the exploitation of resources, the direction of investments, the orientation of technological development, and institutional change are all in harmony and enhance both current and future potential to meet human needs".

Sustainable development is regarded as one of the reactions to ecological destruction caused by industrialization. In the business field, it constitutes a big challenge in all its aspects (stabilization of population, the safety of food, sources from the ecosystems, the economy, and industry). It is based on the economic activity which allows for limited or sensitive use of the Earth's resources and utilizing them with sound judgement (Shirastava \& Hart, 1995). 
In this respect, there is gaining popularity with the concept of the so-called triple bottom line that evaluates business success from the three-pillar point of view of economic, social, and environmental consideration.

Business sustainability may be regarded as a business response to strategies held in a global view towards key aspects of sustainable development. It particularly addresses the broader social value that includes health and human rights support, regional development and fair internalization, complying with environmental regulations through emission technology, the reduction of greenhouse gas and implementation of effective environmental risk management. Sustainable development is about the formation of conditions for a better quality of life for each individual, as known as the future-based ecoefficiency and innovative solutions (CSR Quest, 2011). Kocmanová, Hřebíček and Dočekalová (2011) construe the business sustainability concept as a strategy monitoring long-term business growth, efficiency, performance, and competitiveness through the incorporation of economic, environmental, and social aspects of business management. In doing so, economic growth may accelerate the social progress and improve the environment while the field of social politics may precisely support economic growth simultaneously with efficient environmental policy (Raslanas, Stasiukynas, \& Krutinis, 2012).

It is obvious in regards to these definitions that the business sustainability concept presents a complex issue preferentially aimed at harmonization of economic growth, environmental and social opportunities in the long term and it is oriented to both single business performance and strategy.

Any business needs to be financially selfsufficient to be sustainable in the long term (Finch, 2005). Once this primary requirement is met, a business is in need of being socially responsible. This is achieved by business management and its environmental and social impacts that are self-monitored (self-control) and in accordance with expectations of society and ethical values. Then the business is able to achieve long-term sustainability. Many managerial tools are used to support business sustainability in practice. Examples of tools in an environmental field include environmental accounting, management and reporting as well as life cycle assessment - LCA, net production method, sustainable production design, green marketing, etc. Some tools leaning towards the social area of business sustainability include: the social responsibility standard (ISO 26000), stakeholder engagement standard (AA1000), social accountability and improvement of the workplace conditions standards (SA8000), social audits, programmes for employees support, and business philanthropy (Hahn \& Scheermesser, 2006). We may also add financial-strategic tools to the above list, for example quality management system (ISO 9000), excellence model (EFQM), risk management, performing continuous audits, research and development, benchmarking, etc.

In addition to the tools supporting business sustainability, motives of the concept use and forces that induce a braking in the form of specific barriers are of general interest. Even though a lot of mostly foreign businesses have adopted sustainable entrepreneurship practices, there are still doubts about the advantages of this concept implementation.

With regard to business objectives, it can be said that the business sector will accept the sustainable development concept only when it can appreciate the economic benefits of an environmentally friendly approach and, in regard to respecting socially responsible principles, contribute to a business's economic prosperity (Hyršlová, 2009, p. 10). On the other hand, the enforcement of activities leading to sustainable development also means the incurrence of costs, e.g. purchasing of environmental equipment; implementation of stricter quality control; new health, safety, or environmental programmes. Reporting also includes the costs of data collection, communication and audits. In fact, these costs are incurred immediately while the benefits may only manifest themselves within a longer term (Lourenço et al., 2011).

There are different opinions on the acceptance of sustainable business practices. In the long term, they may bring about an increase in a competitive advantage (as consistent, for instance, with the findings reported by Clar, Feiner and Viehs (2014); Rusinko et al. (2005); Lourenço et al. (2011)), improvement of business's performance (this motive is reported by Adams, Thornton and Sepehri (2012)), or long-term success (reported by, for instance, Goldsmith and Samson (2005); Eccles (2012)). Shirastava and Hart (1995) consider the fact 
that business sustainability has increasingly become a competitive advantage while people and businesses have, as a primary reason, the moral responsibility to minimize their impacts on the planet. Tab. 1 presents several examples of potential motives.

In view of the barriers to the business sustainability implementation, businesses increasingly focus on short-term economic performance rather than the long-term vision of environmental and social sustainability. This fact mainly results from an anthropocentric character and value, whereby the holistic view of entrepreneurship itself is lacking (Setthasakko, 2007; Ionescu-Somers, 2012). This analogously results from McKinsey company's researches (Bonini, 2009). The outline of the selected motives and barriers of business sustainability implementation is shown in Tab. 1.

By identifying the essential barriers constraining particular businesses from implementing the concept, it is possible to know the major obstacles in both the internal and external business environment.

\section{Materials and Methodology}

In order to achieve the goals of the research it was necessary to do a primary survey which was carried out by using a sampling of firms in the Slovak Republic and a subsequent hierarchical cluster analysis.

Depending on the goals, we formulated six hypotheses. We tested the formulated hypotheses with the standard significance level of 5 per cent $(\alpha=0.05)$. To verify the hypotheses, we applied methods of the statistical analysis, e.g. descriptive statistics, frequency and contingency tables, or some types of nonparametric tests (the binomial test, Spearman test, Friedman test, Wilcoxon test).

In the first hypothesis we expected that the majority of surveyed businesses did not have the sustainability concept inherent to their business strategy as a balanced total. The formulation of the first hypothesis is based on the assumption that home businesses do not have the business sustainability concept incorporated in their business strategy as a balanced complex

\section{Tab. 1: Selected motives and barriers to the business sustainability implementation}

Business sustainability

\begin{tabular}{|c|c|}
\hline Motives & Barriers \\
\hline $\begin{array}{l}\text { - eco-innovations } \\
\text { - of technological processes increase } \\
\text { - optimal investment strategies } \\
\text { - cost savings }\end{array}$ & $\begin{array}{l}\text { pressure on short-term earnings by } \\
\text { performance as barrier leading to value } \\
\text { creation }\end{array}$ \\
\hline 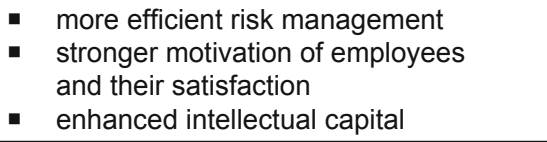 & $\begin{array}{l}\text { business lacks proper competences } \\
\text { and/or abilities } \\
\text { - lack or improper use of key sustainability } \\
\text { indicators }\end{array}$ \\
\hline $\begin{array}{l}\text { - } \\
\text { - improvement of reputation with all key } \\
\text { stakeholders } \\
\text { alleviation of negative effects on health, } \\
\text { property and environment }\end{array}$ & $\begin{array}{l}\text { insufficient support by current organizational } \\
\text { - } \quad \text { structure } \\
\text { sustainability as too low priority }\end{array}$ \\
\hline $\begin{array}{l}\text { - } \quad \text { stronger brand } \\
\text { - } \quad \text { preferences of consumers } \\
\text { - } \text { new products/processes/services }\end{array}$ & $\begin{array}{l}\text { - lack of data and information for sustainable } \\
\text { initiatives implementation } \\
\text { - insufficient involvement of stakeholders }\end{array}$ \\
\hline $\begin{array}{l}\text { focus on new activities } \\
\text { growing market share (attractiveness } \\
\text { to investors) } \\
\text { - shareholders' value enhancement }\end{array}$ & $\begin{array}{l}\text { - lack of stimuli to implementation of } \\
\text { sustainable development activities }\end{array}$ \\
\hline
\end{tabular}

Source: own elaboration based on Porrit (2003); Hyršlová (2009, p. 10-11); Bonini (2012); Berns et al. (2009) 
but they only have areas selected from the three pillars of business sustainability concept (economic, environmental, and social). Therefore, we also assumed that businesses did not apply this concept by reason of insufficient understanding, whereby many of them find the incorporation of the concept into a strategy unnecessary.

In the two following hypotheses we assumed the existence of a mutual relation between the business size $(\mathrm{H} 2)$ as well as the form of ownership (H3) and the intensity of business's involvement in business sustainability. The majority of small and medium-sized enterprises are forced to struggle for the very existence. Businesses do not have sufficient sources of finance available, knowledge and an intention to apply sustainable development principles. It is mostly large foreign owned businesses which have better opportunities to implement sustainable and responsible entrepreneurship principles (Bussard et al., 2005).

The fourth hypothesis concerns the tools used by businesses. We assumed that industrial businesses used more social tools than environmental ones. It can be considered that business sustainability is enforced by different tools that may be different in nature. We based this assumption on environmental tools that are financially as well as technologically more intensive for businesses compared with social ones.

The last two hypotheses were related to motives and barriers to the business sustainability concept in use. In $\mathrm{H} 5$ we expected the improvement in operational efficiency was the main motive of the business sustainability implementation or the motive leading to its use. There are several motives leading to the concept implementation and bring various benefits to businesses. These advantages are not always immediately visible as a period of time is often needed. An example of this may be the cost reduction resulting from the use of a different, more economical technology. In some cases an effort to achieve a better reputation may be the only motive, whereby the real reason for concept implementation is rather questionable. In our view, reaching the assurance of long-term performance, which is rather difficult in the present short-term, is the cardinal motive for businesses.

In the hypothesis $\mathrm{H} 6$ we assumed the pressure to make short-term gains to be the largest barrier to the business sustainability implementation. This manifests itself namely by the businesses' concentration on short-term profit in an effort to avoid financial distress.

We carried out the business sustainability analysis by means of a selected sample of businesses through an electronic survey. The aim was to determine the ways in which selected industrial businesses address the three sustainability dimensions: economic, environmental, and social. We also wanted to determine which tools are prevailingly used and what are the underlying motives and barriers.

We targeted all size categories of enterprises except for microenterprises (enterprises up to ten employees) based on the 2003/361/EC Commission Recommendation (http://eur-lex.europa.eu). We decided to exclude microenterprises from the entire sample, mainly on account of the subject and focus of the analysis. The issues of sustainable development and their connection with the business strategy are exceedingly demanding for microenterprises. These businesses mostly battle over their survival while the strategic approach is often missing.

The ownership structure (i.e., the domestic, foreign, mixed capital participation) is one of characteristic business identities with a decisive influence. As seen in many research, the application of the business sustainability concept is predominantly made by foreign businesses.

We explored the sustainability concept in businesses operating in certain selected industries. This decision was mainly because the necessity to study the environmental dimension of sustainable resource and their adequate preservation for future generation. The relationship between industry and its direction towards sustainable development is particularly apparent with the improvement of manufacturing methods based on technologies and processes in the reduction of waste production. The introduction of technological innovations, their development, strategy for cleaner production or building of a complex partnership is created within the industrial field (Agenda 21, 2001). Nemcová (2012, p. 62) views the industrial impact on the environment from two perspectives, namely the impact of the environment and the impact of consumption, i.e. the use of products from that particular industry. As she indicates, the majority of problems relating to the consumption of an industrial 
product are wide in scope. The environmental impact of industrial production pertains to the competences of each industry as it concerns their ability to act on the technologies and innovations that are the key to solving the above problems.

To analyse the results of the research and survey, we employed Microsoft Excel which helped us evaluate the frequency distribution. We used the SPSS software to verify the formulated hypotheses. Based on obtained information, we could explore a relationship among word characters by means of the so-called contingency analysis. We also grouped selected respondents' answers into contingency tables which enabled us to explore the existence of the relationship among the above characters.

We also used multidimensional structural methods. These methods are used mainly to explore the structure in large disarranged data matrices and correlation matrices. The hierarchical cluster analysis inter alia belongs to the fundamental methods (Bezvoda \& Blahuš, 2007). Its aim was to form groups of mutually similar components, namely based on objects, their attributes, or their combination. The aim of the cluster analysis was to find a set of business clusters with the approximately the same or similar approach to business sustainability. In doing so, we applied agglomerative clustering where single clusters are iteratively merged to larger agglomerates. We specified the number of clusters in the 3 to 4 range in the SPSS software. The Euclidean distance between two vectors was most often used. There are several methods of clustering (e.g., the group merging method, centroid-based clustering, nearest and furthest neighbour methods, Ward's method, etc.). Based on the complete linkage clustering, we considered the furthest neighbour the most appropriate, whereby the distance between the two clusters is defined as a distance of two of the furthest members. In the SPSS software there are results of single steps summarised and displayed in the agglomeration schedule which displays a closeness matrices providing information about distances among objects and clusters. At the beginning, we consider each object to be an independent cluster and subsequently the clustering process was initialized. The result of the hierarchical cluster analysis is displayed in a tree diagram, a dendrogram, in which each knot represents one phase of the clustering process.

\section{Results and Discussion}

The survey research was carried out from October 2014 to January 2015. After the selection based on the chosen criteria, we obtained a database containing 2,793 businesses. From this list, we were able to deliver 2,125 questionnaires from which 501 were completed. We excluded 46 businesses owing to missing data. Thereby we could analyse 455 correctly completed questionnaires resulting in a response rate of 21.41 percent.

\section{Tab. 2: Verification of survey sample representativeness according to the enterprise size}

\begin{tabular}{l|r|r|r} 
& \multicolumn{2}{|c|}{ Observed N } & \multicolumn{2}{c}{ Expected N } & \multicolumn{2}{c}{ Residual } \\
\hline Small enterprise & 287 & 297.3 & -10.3 \\
\hline Medium-sized enterprise & 128 & 120.9 & 7.1 \\
\hline Large enterprise & 40 & 36.8 & 3.2 \\
\hline Total & 455 & & \\
\hline
\end{tabular}

Test Statistics

\begin{tabular}{l|r}
\hline & \multicolumn{1}{|c}{ Enterprise size } \\
\hline Chi-Square & 1.051 \\
\hline Df & 2 \\
\hline Asymp. Sig. & 0.591 \\
\hline
\end{tabular}


In order to verify sample representativeness, we applied the Chi-squared test of homogeneity. We chose the enterprise size and main line of business or industry sector respectively as two fundamental representativeness characters according to which representativeness was evaluated. In term of the enterprise size, we may consider the survey sample representative at the 5 percent level of significance $(p$-value $=0.591)$.

The following tables present the output of the statistical SPSS software which was used to verify sample representativeness in term of the enterprise size and main line of business. As it results from the data in Tab. 2, the structure of the population is met by the survey sample according to the enterprise size.

Accordingly, verification of sample representativeness according to the main line of business also allows us to consider the survey sample representative in term of the second character - the main line of business presented in Tab. 3 ( $p$-value = 0.052).

The sample distribution in term of the industry sector and enterprise size presented in absolute values is shown in Tab. 4.

We assess positively the fact that almost three quarters of all respondents belong to higher management as these respondents should understand the business and its strategic direction more clearly.

\subsection{The Implementation of the Business Sustainability Concept in Surveyed Businesses According to Determined Criteria}

We consider the expression of the respondents' attitude to their treatment of particular

\section{Tab. 3: Verification of survey sample representativeness according to the main line} of business

\begin{tabular}{l|r|r|r}
\multicolumn{1}{c|}{ Main line of business } & \multicolumn{1}{c|}{ Observed N } & \multicolumn{1}{c}{ Expected N } & \multicolumn{1}{c}{ Residual } \\
\hline Mining & 14 & 9.0 & 5.0 \\
\hline Leather industry & 8 & 11.2 & -3.2 \\
\hline Wood-processing and furniture industry & 56 & 60.6 & -4.6 \\
\hline Pulp and paper industry & 20 & 21.8 & -1.8 \\
\hline $\begin{array}{l}\text { Chemical industry, manufacturing of } \\
\text { rubber and plastic products, coke and } \\
\text { refined petroleum products }\end{array}$ & 59 & 60.6 & -1.6 \\
\hline Pharmaceutical industry & 4 & 2.5 & 1.5 \\
\hline Metallurgical industry & 12 & 11.2 & .8 \\
\hline $\begin{array}{l}\text { Engineering industry (including } \\
\text { automotive) }\end{array}$ & 202 & 193.2 & 8.8 \\
\hline Electrical engineering & 42 & 46.3 & -4.3 \\
\hline $\begin{array}{l}\text { Manufacturing of other non-metallic } \\
\text { mineral products }\end{array}$ & 19 & 28.8 & -9.8 \\
\hline Other production & 19 & 9.8 & 9.2 \\
\hline Total & 455 & & \\
\hline
\end{tabular}

Test Statistics

\begin{tabular}{l|r}
\hline & \multicolumn{1}{|c}{ Main line of business } \\
\hline Chi-Square & 18.176 \\
\hline Df & 10 \\
\hline Asymp. Sig. & .052 \\
\hline
\end{tabular}




\begin{tabular}{|c|c|c|c|c|}
\hline $\begin{array}{l}\text { Industry sector/enterprise size } \\
\text { (number of employees) }\end{array}$ & $\begin{array}{c}\text { Small } \\
\text { enterprise } \\
(10-49)\end{array}$ & $\begin{array}{l}\text { Medium- } \\
\text { sized } \\
\text { enterprise } \\
(50-249)\end{array}$ & $\begin{array}{c}\text { Large } \\
\text { enterprise } \\
(250+)\end{array}$ & Total \\
\hline Mining & 13 & 0 & 1 & 14 \\
\hline Leather & 3 & 3 & 2 & 8 \\
\hline Wood-processing, furniture & 44 & 12 & 0 & 56 \\
\hline Pulp and paper, printing & 12 & 5 & 3 & 20 \\
\hline $\begin{array}{l}\text { Chemicals, manufacturing of rubber and plastic } \\
\text { products, coke and refined petroleum products }\end{array}$ & 33 & 18 & 8 & 59 \\
\hline Pharmaceuticals & 3 & 0 & 1 & 4 \\
\hline Metallurgy & 6 & 4 & 2 & 12 \\
\hline Engineering (incl. automotive) & 118 & 67 & 17 & 202 \\
\hline Electrical & 20 & 17 & 5 & 42 \\
\hline Other non-metallic mineral products & 16 & 2 & 1 & 19 \\
\hline Other & 19 & 0 & 0 & 19 \\
\hline Total & 287 & 128 & 40 & 455 \\
\hline
\end{tabular}

Source: own elaboration based on the survey research results

dimensions of business sustainability to be crucial in the research. The options led us to create a sequence of a potential business direction, i.e. from the option of survival through the occasional direction, systematic and long-term engagement in a certain field, to incorporation of that field into the business strategy. The objective was to find out how particular businesses pursue the fields in question in their activities. We were primarily interested in the number of businesses which have all three concept fields incorporated in their business strategy in addition to that they follow them systematically and on a longterm basis. As indicated in Fig. 1, only the combinations we regarded as underlying these concepts were chosen.

Based on the obtained responses, we divided the businesses into the following categories:

An occasional focus on particular areas: in this group, small businesses occasionally are focusing on all three areas. Medium-sized enterprises occasionally focus on social and environmental issues to a larger extent. Only 3.78 percent of large enterprises occasionally focus on the economic area.

Businesses primarily focusing on the environmental or social areas: as a result of the ratio of focus of one or another area being relatively similar (151/176). When mutually compared, businesses tend to be more engaged in the social area. In all businesses the environmental area slightly lags behind (the differences are 17 within small businesses and only 4 medium-sized and large businesses). The result is also similar in respect to the capital structure rate. All businesses pay attention to the environmental area with the exception of the leather industry. All examined industries are represented in the social area.

The systematic focus on the all three areas: based on the results of the research we included 67 businesses to this group; the majority of them are small businesses with a 63 percent share; medium-sized enterprises having a 34 percent share; and large businesses only 1.5 percent. In this group, domestically owned businesses prevail with 50 businesses, 10 businesses are foreign-owned and 7 businesses with mixed ownership. The group contains no mining, leather or pharmaceutical businesses.

Businesses having the all three areas incorporated in the strategy: this group contains 44 businesses that have all areas incorporated into the business strategy. As can be seen in Figure 1, half of them are mediumsized businesses (50 percent). The rest is 
represented by small businesses (27 percent) and large businesses (almost 23 percent). If we take the size structure of businesses into account, 10 large businesses out of 40 have the areas incorporated in their strategy. The same applies to 22 medium-sized businesses out of 128 and only 12 small businesses out of 287. As we were expecting, larger businesses are more engaged in the strategy than small or medium-sized ones. In terms of ownership, there are 14 domestically owned, 25 foreignowned businesses and 5 businesses with mixed ownership in this group. All industries, with the exception of wood-processing and furniture and other production, are represented. As for the explicit focus on environmental or social areas in the strategy, the social area is prevailing in small businesses, in medium-sized and large enterprises the environmental area dominates.

Based on the research results we can assume that the majority of surveyed businesses do not have the concept of business sustainability incorporated in their business strategy as a balanced complex.

\section{Fig. 1: The business focus on business sustainability concept areas according to the enterprise size}

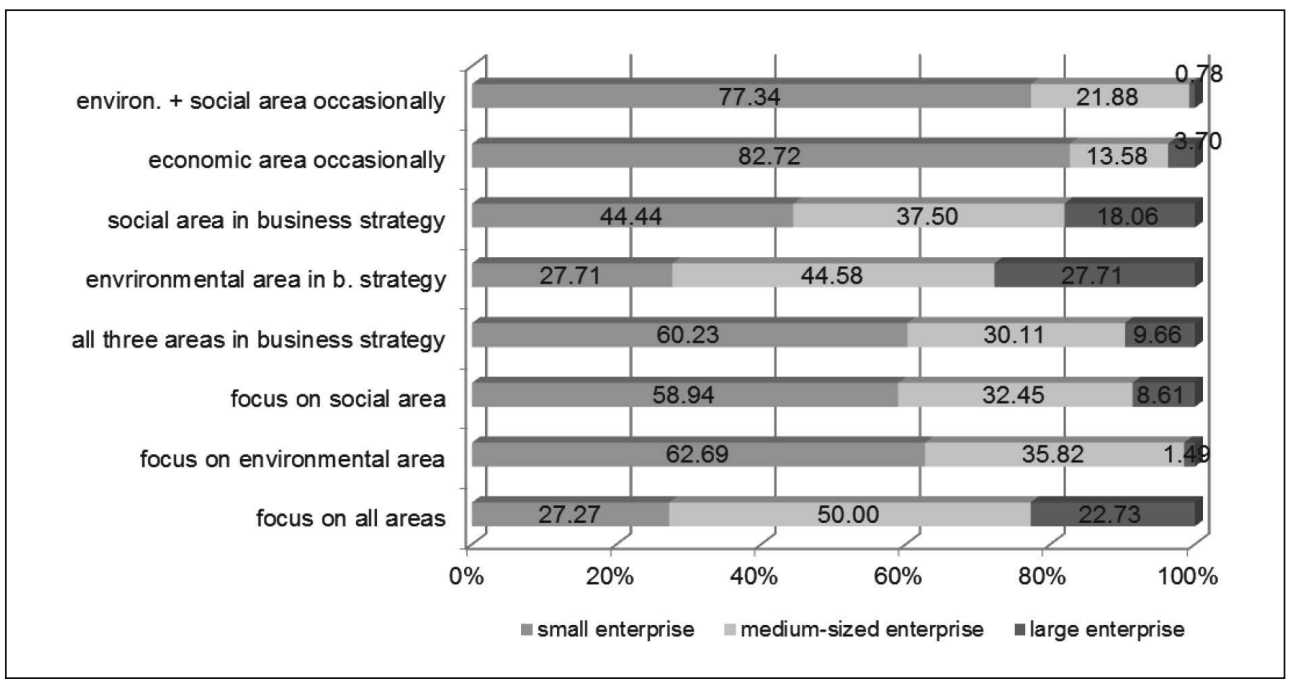

Source: own elaboration based on the survey research results

In the research we were also interested in the sustainability concept implementation in relation to variables such as the business size and business ownership. That means whether these variables influence a business's involvement in the sustainability concept. Based on that we constructed the $\mathrm{H} 2$ hypothesis, it was assumed that there is a dependence between the intensity of business's involvement in sustainability issues and its size. To verify the hypothesis we applied an independence test and the Spearman's correlation coefficient to determine the strength of the dependence between variables. This independence test and Spearman's correlation coefficient value resulted in a finding of ( $p$-value $=0$, Spearman's coefficient $=0.373$ ). As such, there is a moderate positive dependence between variables. The strongest dependence is observed in the area of environmental opportunities. This implies that the larger the business the more intensive focus is on environmental issues and social opportunities.

In the H3 hypothesis, we explored the existence of the dependence between a business's involvement in sustainability issues and forms of ownership. To verify the hypothesis we applied the Chi-square test of independence. We discovered that the analysed variables were not independent $(p$-value $=0)$. 


\section{Tab. 5: The results of hypothesis verification}

\begin{tabular}{c|l|c|c|c}
$\begin{array}{c}\text { Order of } \\
\text { hypotheses }\end{array}$ & \multicolumn{1}{|c|}{ Hypothesis fundamentals } & Decision & p-value & $\begin{array}{c}\text { Dependence } \\
\text { strength }\end{array}$ \\
\hline H2 & $\begin{array}{l}\text { there is a dependence between business } \\
\text { size and the intensity of its involvement in } \\
\text { business sustainability }\end{array}$ & confirmed & 0 & moderate \\
\hline H3 & $\begin{array}{l}\text { there is a dependence between business's } \\
\text { involvement in business sustainability and } \\
\text { the form of ownership }\end{array}$ & confirmed & 0 & moderate \\
\hline
\end{tabular}

Source: own elaboration of the SPSS outputs

In order to determine the dependence strength we use the Cramer's $V$ correlation coefficient. As the results indicated $\left(C_{v}=0.243\right)$, there was a moderate dependence between variables, i.e., similarly as above, the concept implementation is also affected by ownership structure.

Tab. 5 provides the results of the hypotheses 2 and 3 tests also showing the dependence strength of both examined variables.

As stated in the theoretical part, business sustainability also manifests itself by means of tools which may help a business's approach to sustainability. According to the areas which are predominantly affected by the tools, we classified them into tools in the strategicfinancial, environmental and social areas. The results evidently indicate that, within the strategic-financial area, industrial businesses employ the STN ISO 9001 management system most often (298 respondents; 66.08 percent), they realize customer satisfaction researches (263 respondents; 58.31 percent), or perform continuous audits (249 respondents; 55.21 percent). The least used tool in this group is the EFQM excellence model (9 respondents; 2 percent). Approximately 11 percent of respondents employ green marketing and crisis management. 28 respondents (6.21 percent) denoted the alternative "other". This comprised the tools such as: ISO 9001 without certification, the ISO TS 16949 system, own, the FSC certificate, the introduction of new licences and certificates, SWOT, STEP, the Porter's model, projecting, OCAB OCBC, ECM ISO 3834, the GMP certificate, ISO 27000 , the "more to employees less to the state" model. The most frequently used tool in this group is the ISO TS 16949 standard.
Tools belonging to the environmental category that are mostly used by industrial businesses include clean production (189 respondents; 44.16 percent) followed by the STN EN ISO 14001 standard (128 respondents; 29.91 percent). Almost 84 respondents (20 percent) utilize renewable resources. Environmental reporting (40 respondents; 9.35 percent) and ecolabelling (23 respondents; 5.37 percent) were used less often (less than 10 percent). Less than 20 respondents measure their carbon track, they have introduced environmental accounting, follow product life-cycle assessment (LCA), or environmental benchmarking. The ecological track is not represented at all. The alternative "other" was denoted by 23 respondents (5.37 percent). The examples here include: regeneration and the repeated raw material use in the production, the PEFC certificate, BAT, according to the Green Technology concept, OCAB OCBS. The responses reveal that 9 businesses do not use any tools or are not involved in the environmental area.

The most frequently used tools were within the area of motivational tools used in relation to their employees with courses, educational trainings, healthcare, etc. (238 respondents; 53.48 percent). Less than half of businesses (205 respondents; 46.07 percent) use customer satisfaction researches; women and men employment equality is declared by 194 respondents (43.60 percent) and 188 respondents (42.25 percent) engaged in sponsoring activities. The least represented tools were the use of the social responsibility standard and SA8000 improvement of workplace conditions standard (7 respondents; 1.57 percent), a social audit was carried out 
only by 9 respondents (2.02 percent), and the STN ISO 26000 Social Responsibility Direction, which is almost identical as for the contents, was used only by 12 respondents (2.70 percent). The AA1000 standard pertaining to management of stakeholders is not used by any of the addressed businesses. In this area 4 businesses do not use any tools.
The number of tools falling in the environmental and social areas raises deep concern within the analysis but also the way the tools are combined in each area, e.g. not only the use of environmental tools, or, contrary, only social ones. This was plotted (in absolute values) in the Fig. 2 below.

\section{Fig. 2: The comparison of businesses according to tools used in environmental and social areas}

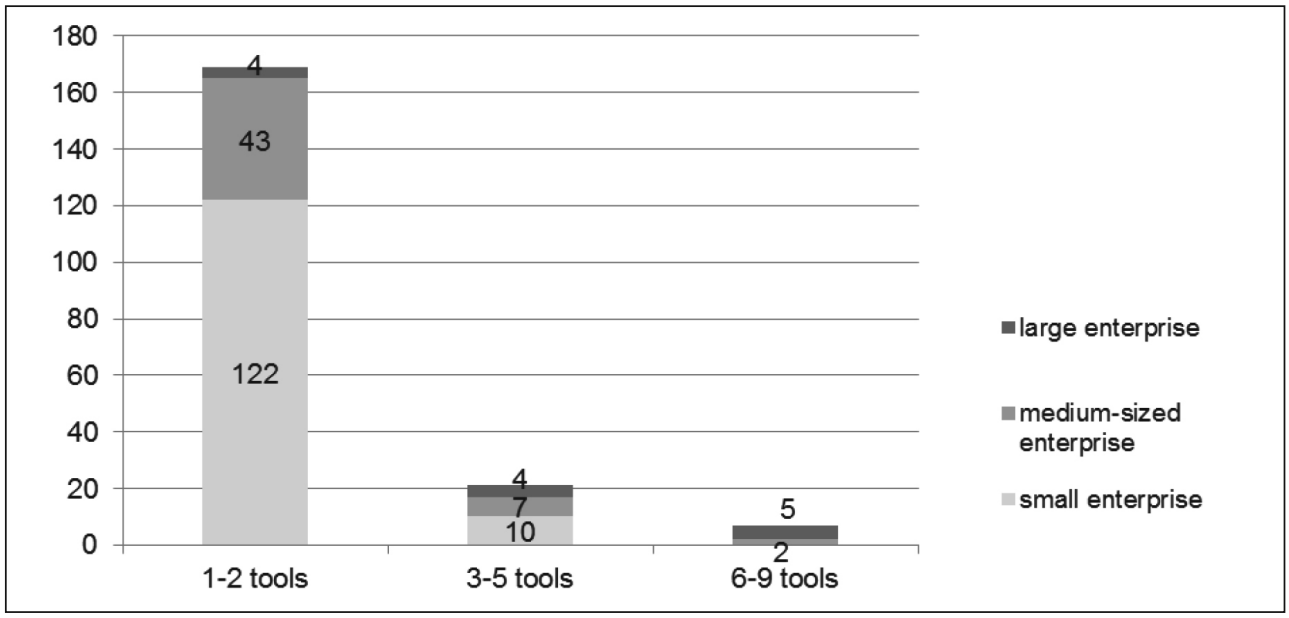

Source: own elaboration based on the survey research results

In respect to business sustainability, reasons or motives which make businesses focus not only on economic performance but also on environmental and social activities that may also boost performance are essential. The inquiry results regarding the most important motives are presented in Tab. 6.

The differences among businesses as to their size structure are not significant. Marginal deviations only occurred in some cases. In small businesses, the ability to attract talented employees and differentiation from competitors are more essential while reputation and the ecological and social responsibility are more important for medium-sized enterprises. Public pressure is considered the least important by businesses. In contrast to these groups of businesses, large enterprises saw several motives to be equally important. The improvement of reputation and ecological and social responsibility for their activities are foremost. They find risk monitoring in a business significant as well.

The addressed businesses could also add other motives they considered significant. The examples include sanctions avoidance (in terms of legislation), dust nuisance reduction, personal conviction of management, efforts to achieve exceptional quality, efforts to hold foreign markets, education of new state-ofthe-art trades for foremen, accountability, or facilitation of heavily disabled persons.

Besides the above results of the survey research, Tab. 6 also shows the results of researches realized abroad related to motives of business sustainability. Our comparison is based on the results of a global research conducted by the McKinsey company and a local research realized in cooperation of the Institute for Sustainable Enterprise and the Public Mind and Fairleigh Dickinson University in New Jersey. The data in the table indicate that, within the 
Most important motives of implementation of business sustainable development concept

\begin{tabular}{l|l|l}
\hline \multicolumn{1}{c|}{$\begin{array}{c}\text { Results of our own survey } \\
\text { research }\end{array}$} & \multicolumn{1}{c}{$\begin{array}{c}\text { Results of foreign research } \\
\text { (McKinsey) }\end{array}$} & $\begin{array}{c}\text { Results of foreign research } \\
\text { (New Jersey) }\end{array}$ \\
\hline 1. meeting customers' demands & $\begin{array}{l}\text { 1. business reputation } \\
\text { improvement }\end{array}$ & 1. belief in the right thing \\
\hline $\begin{array}{l}\text { 2. improvement of operational } \\
\text { efficiency }\end{array}$ & $\begin{array}{l}\text { 2. alignment with business } \\
\text { objectives }\end{array}$ & 2. potential cost reduction \\
\hline 3. sales and profit growth & $\begin{array}{l}\text { 3. operational efficiency } \\
\text { improvement }\end{array}$ & $\begin{array}{l}\text { 3. satisfaction of customers' } \\
\text { requirements }\end{array}$ \\
\hline $\begin{array}{l}\text { 4. new growth opportunities } \\
\text { (new products, new markets) }\end{array}$ & $\begin{array}{l}\text { 4. satisfaction of customers' } \\
\text { requirements }\end{array}$ & $\begin{array}{l}\text { 4. potential image and reputation } \\
\text { improvement }\end{array}$ \\
\hline $\begin{array}{l}\text { 5. attracting talented employees } \\
\text { and productivity increase }\end{array}$ & $\begin{array}{l}\text { 5. growth opportunities, } \\
\text { new products }\end{array}$ & $\begin{array}{l}\text { 5. support of healthy } \\
\text { and well-performing company }\end{array}$ \\
\hline $\begin{array}{l}\text { 6. possibility to differentiate from } \\
\text { competitors }\end{array}$ & $\begin{array}{l}\text { 6. strengthening competitive } \\
\text { position }\end{array}$ & $\begin{array}{l}\text { 6. meeting legal/regulation } \\
\text { requirements }\end{array}$ \\
\hline $\begin{array}{l}\text { 7. business reputation and image } \\
\text { improvement }\end{array}$ & $\begin{array}{l}\text { 7. personal priorities } \\
\text { of management }\end{array}$ & $\begin{array}{l}\text { 7. securing future availability } \\
\text { of key natural resources }\end{array}$ \\
\hline $\begin{array}{l}\text { 8. ecological and social } \\
\text { responsibility for own activities }\end{array}$ & 8. risk regulation & $\begin{array}{l}\text { 8. potential of new markets } \\
\text { and customers }\end{array}$ \\
\hline $\begin{array}{l}\text { 9. business risk monitoring and } \\
\text { reduction }\end{array}$ & 9. attracting talents & $\begin{array}{l}\text { 9. satisfaction of current and } \\
\text { potential employees' interests }\end{array}$ \\
\hline $\begin{array}{l}\text { 10. pressure from public, } \\
\text { government, non-profit } \\
\text { organizations }\end{array}$ & $\begin{array}{l}\text { 10. pressure from non-profit } \\
\text { organizations }\end{array}$ & $\begin{array}{l}\text { 10. satisfaction of shareholders'l } \\
\text { investors' interests }\end{array}$ \\
\hline
\end{tabular}

Source: own elaboration based on the survey research results; Bonini (2012); Harmon et al. (2012)

first three most important motives, meeting customers' requirements, the improvement of operational efficiency, and the sales and profit growth are prevailing in the domestic research. The global research results point to such motives as reputation improvement, the alignment with business objectives and efficiency, while the results of the local foreign research emphasize the belief in the right thing and only after that, cost reduction or customers' satisfaction. To sum up, all aforementioned motives with some exceptions have approximately the same nature. These exceptions lie for instance in that we rank profit and sales as an important and decisive motive. Shareholders'/investors' interests occupy the last positions in the local research. Along with that the tendency towards feelings about "doing the right thing" or accountability predominates here. The differences in the results of motives perceived by businesses in the foreign global and local researches reside chiefly in the feeling of the belief in the right thing as well as support for society as a whole.

In the analysis of business sustainability we also were concerned with potential barriers to implementing business sustainability concepts that was perceived by respondents. Similarly as for motives, there were no significant differences in their perception related to the business size noted. Only 14 respondents (3.08 percent) did not provide their opinion on the issue and 36 respondents (8.16 percent) did not know the answer. The following barriers are deemed the most crucial by the surveyed businesses:

- insufficient sources of finance (322 respondents; 73.02 percent),

- lack of stimuli to focus on the all three concept areas (224 respondents; 50.79 percent),

- pressure to generate short-term gains predominates over long-term business sustainability (137 respondents; 31.07 percent), 
- insufficient evaluation and measurement of environmental impacts (134 respondents; 30.39 percent),

- shortage of proper capabilities and/or skills (57 respondents; 12.93 percent),

- a low priority on the concept placed by management (40 respondents; 9.07 percent),
- others, i.e. an inadequate state burden (without a counter-value), the competitive environment does not behave in an eco-friendly way, administrative burden, legislation, too many regulations, too many nonpayers (7 respondents; 1.59 percent).

Tab. 7 reports the research results concerning hypotheses $\mathrm{H} 4-\mathrm{H} 6$.

\section{Tab. 7: The results of hypotheses verification}

\begin{tabular}{c|l|c|c}
$\begin{array}{c}\text { Order of } \\
\text { hypotheses }\end{array}$ & \multicolumn{1}{|c|}{ Hypothesis fundamentals } & Decision & p-value \\
\hline H4 & $\begin{array}{l}\text { industrial businesses apply more social than } \\
\text { environmental tools }\end{array}$ & confirmed & 0 \\
\hline \multirow{3}{*}{ H5 } & $\begin{array}{l}\text { improvement of operational efficiency is } \\
\text { a primary motive of business sustainability } \\
\text { implementation or moving into this direction }\end{array}$ & $\begin{array}{c}\text { partially } \\
\text { confirmed }\end{array}$ & 0.369 \\
& $\begin{array}{l}\text { pressure on short-term profit generation rather } \\
\text { than long-term performance is biggest barrier } \\
\text { H6 }\end{array}$ & rejected & 0.003 \\
\hline & to focus on business sustainability & & \\
\hline
\end{tabular}

Source: own elaboration of the SPSS outputs

\subsection{The Comprehensive View of the Concept Use Based on the Cluster Analysis}

With the aim of providing a more comprehensive insight into businesses in selected industries, we applied the hierarchical cluster analysis. This analysis was used to break businesses up into clusters according to their approach to business sustainability. The following survey criteria were analysed:

- involvement in the given concept area (economic, environmental, social ones),

- motives or reasons of engagement in environmental as well as social commitments,

- the number of management tools in the environmental and social area.

The results of the cluster analysis show different approaches to sustainability in a more detailed and precise way. The sample of businesses consisted of 357 businesses. 98 businesses did not respond to some questions so that they were excluded from the clustering process. With regard to the ordinal variables and analysis objects, we applied Chi-square measures of distance among the objects of clustering using the furthest neighbour method
(Complete Linkage). The resulting agglomerate scheme describing distances between objects and clusters is not presented in the paper due to capacity reasons (it contains 357 entries).

On the basis of detailed information concerning 357 businesses and through the use of the hierarchical cluster analysis three clusters of businesses were identified. These clusters were classified according to particular characteristics as follows:

- "traditionalists"

businesses;

\subsection{5 percent),}

- "more social-economic" (209 businesses; 58.54 percent),

- "being on the way to sustainability" (50 businesses; 14.01 percent).

All three clusters (Fig. 3) represent businesses devoting themselves to the economic area in a rather long term and systematically. A minimum number of businesses dealt with this issue only occasionally. The given clusters differ from one another in the aforementioned criteria and are specified in the description of particular clusters.

The "traditionalists" cluster consists of 98 businesses and is characterized by a weaker emphasis on the environmental and 


\section{Fig. 3: The classification of businesses based on the cluster analysis}

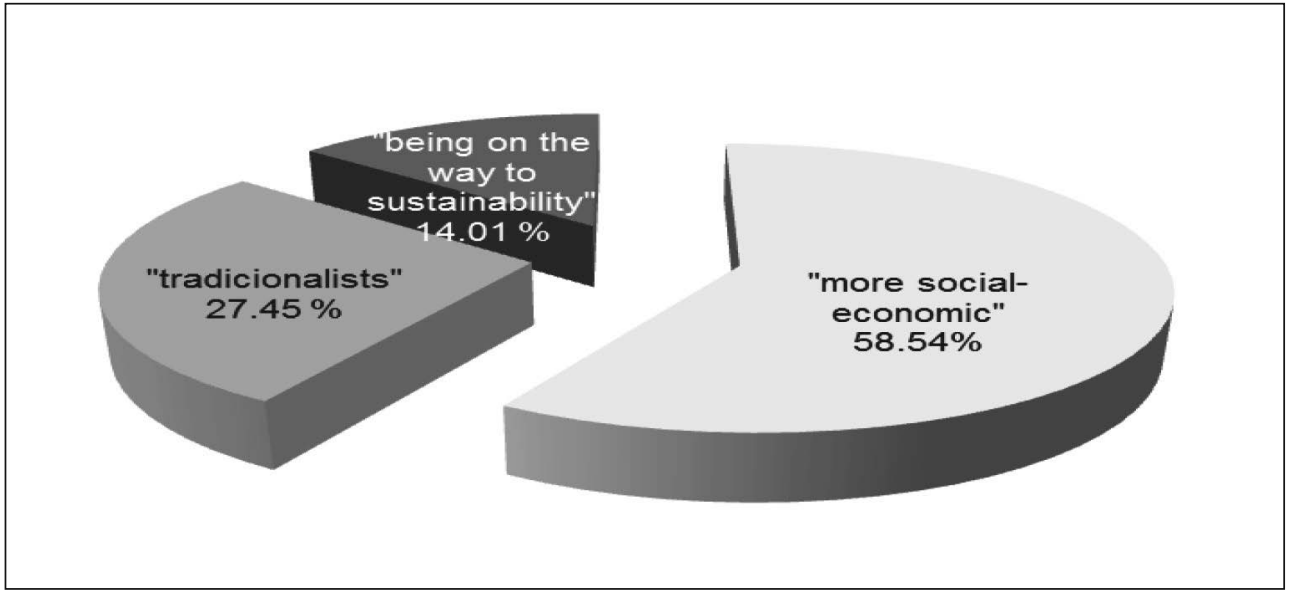

Source: own elaboration based on the results of the hierarchical cluster analysis

social areas. Businesses in this cluster address themselves to these areas to an extent allowed by their very survival or if an occasion arises (75.51 percent). Talking in terms of motives of the focus on given areas, meeting customers' requirements (41.84 percent and sales and profit growth (36.73 percent) dominate, and the last of key motives is operational efficiency improvement (34.69 percent). We treat these motives as so called traditional ones and the cluster name was derived from them. Businesses in this cluster use few environmental and social tools ( 3 tools maximally). The use of one tool dominates in the environmental area (78.57 percent). Businesses use one tool (62.24 percent) or two tools (18.37 percent) in the social area. The priority attributed to the balance of the economic, environmental, and social areas by businesses is moderately high (37.76 percent) to low (35.71 percent).

The cluster representing most businesses (209) contains "more social-economic" businesses since they are involved in the social-economic area to a larger extent that in the environmental one. The main motives are: meeting customers' requirements (68.42 percent), efficiency improvement (62.68 percent), and sales and profit growth (57.89 percent). Compared to the previous cluster, the order changed here results in businesses placing less emphasis on gains.
As for the tools of the environmental area, the businesses use one tool (66.51 percent) or two tools (20.57 percent), and five tools at most. Three to four tools (25.84 percent and 20.57 percent respectively) dominate in the social area. The priority attributed to business sustainability in this group is quite high (50.00 percent) and moderately high (32.04 percent).

The last cluster labelled as "being on the way to sustainability" comprises businesses characterized mostly by the strong interest in the environmental (86.00 percent) and social area (82.00 percent). The most significant motives of this cluster include meeting customers' requirements (76.00 percent), operational efficiency improvement (70.00 percent), and the ecological and social responsibility (64.00 percent). Concurrently, the number of tools employed in particular areas is apparently higher. The use of five tools (22.00 percent) dominates in the environmental area and the number of the tools used is two to five. The number of tools used in the social area is substantially higher: seven tools (22.00 percent) and six tools (20.00 percent). The high priority (48.00 percent) and lower priority (38.00 percent) predominate. The figure above illustrates the classification of businesses.

It may be observed that particular clusters have their own characteristics. Businesses in 
the "being on the way to sustainability" cluster converge with the sustainability concept. In this phase, they may not be labelled as sustainability leaders yet since they still have their limitations. They represent the smallest group in the research. The positive trend appearing in this group is the motive of the ecological and social responsibility which is typical just of businesses understanding sustainability to be crucial not only in their view. The incorporation of environmental and social issues into a strategy characterizes this group. It also employs the most tools. The "traditionalists" are primarily involved in economic issues. Their motives also represent traditional objectives for customers, gains, and efficiency. They attach the lowest priority to the concept. The "more socialeconomic" cluster, with its character, is closer to the "traditionalists" cluster than to the "on the way to sustainability" one.

\section{Conclusion}

This paper is focused on the analysis of the current state of sustainability concept implementation in businesses in selected industries. We analysed the environmental, social and financial-strategical tools used by businesses in more detail as a supporting component in the implementation of the business sustainability concept. Based on the analysis we provide a more comprehensive overview of businesses' approach to the sustainability concept by means of a hierarchical cluster analysis.

Our assumption was confirmed that the majority of businesses do not have the concept incorporated in their strategy as a balanced complex as it was declared only by 44 businesses. When looking at the priority focus of businesses on the environmental and social areas of the concept, the rate of focus on one or the other area was relatively similar, however, as the results are from a mutual comparison, businesses were more involved in social area. The social tools were more often used by industrial businesses than environmental ones. The more detailed examination revealed the dominance of "more classical" tools such as a quality management system, realization of audits, etc. The more specialized tools, such as benchmarking or environmental reporting, were less represented. In terms of motives of the implementation and realization of activities in accordance with business sustainability, meeting the customers' requirements, operational efficiency improvement, or sales growth were prevailing. On the basis of that it can be argued that businesses focus on more traditional motives. Other motives were cited in foreign researches as "doing the right thing" as perceived by businesses. Concerning the barriers to sustainability concept implementation in business, the shortage of financial sources to perform these activities; the lack of stimuli to focus on all three concept dimensions; or pressure on short-term gains rather than longterm business sustainability prevailed.

Based on the more comprehensive survey of businesses in terms of the business sustainability concept and by means of the hierarchical clusteranalysis, itcan beestablished that most businesses were represented in the cluster aimed at the social-economic area which is also indicated by the contents of motives or tools used in business practice. The second in line was the "traditionalists" cluster in which traditional tools, motives, and the priority attributed to the business sustainability concept predominated. Businesses heading for the business sustainability concept implementation are a part of the least represented cluster. However, there were only 14 percent of businesses with a sense for ecological and social responsibility.

The presented analyses and facts demonstrate several possibilities of improving the present state of the business sustainability concept implementation which could be beneficial for a business in the broader environment. Dealing with these issues, however, requires not only involvement of the business sector but also interaction on the part of the state.

\section{References}

Adams, M., Thornton, B., \& Sepehri, M. (2012). The Impact of the Pursuit of Sustainability on the Financial Performance of the Firm. Journal of Sustainability and Green Business, 1. Retrieved from http://www.aabri. com/jsgb.html.

Agenda 21 and Sustainable Development (2001). The Declaration adopted at the UN Conference on Environment and Development in Rio de Janeiro held from 3 to 14 July 1992. Bratislava: the Ministry of environment SR. Retrieved April 10, 2015, from http://www. minzp.sk/files/dokumenty/agenda21-sk.pdf. 
Berns, M., Townend, A., Khayat, Z., Balagopal, B., Reeves, M. Hopkins, M. S., \& Kruschwitz, N. (2009). Sustainability and competitive advantage. MIT Sloan Management Review, 51(1), 18-26.

Bezvoda, V., \& Blahuš, P. (2007). Financial Mathematics and Statistics. Praha: College of Banking.

Bonini, S. (2012). The business of sustainability. McKinsey on Sustainability \& Resource Productivity. Retrieved January 27, 2013, from https://www.mckinsey.com/ /media/ mckinsey/dotcom/client_service/Sustainability/ PDFs/McK\%20on\%20SRP/SRP_11_Biz\%20 sustainability.ashx.

Bussard, A., Marček, E., Markuš, M., \& Bunčák, M. (2005). Corporate Social Responsibility. Overview of Basic Principles and Examples. Bratislava: Integra Foundation. Retrieved January 20, 2014, from http:// www.panet.sk/download/text_zodpovedne_ podnikanie.pdf.

Clark, G., Feiner, A., \& Viehs, M. (2015). From the Stockholder to the Stakeholder. How Sustainability Can Drive Financial Out Performance. Retrieved December 27, 2014, from https://arabesque.com/research/From_ the_stockholder_to_the_stakeholder_web.pdf.

Corporate social responsibility quest. (2001). A multi dimensional view of corporate responsibility. Retrieved March 13, 2013, from http://www.csrquest.net/default. aspx?article $\mid \mathrm{D}=13113$ \&heading $=$.

Eccles, R. (2012, January 6). Is sustainability now the key to corporate success? The Guardian. Retrieved March 20, 2014, from http://www.theguardian.com/sustainablebusiness/sustainability-key-corporate-success.

Finch, N. (2005). The motivations for adopting sustainability disclosure [MGSM Working Paper No. 2005-17]. Sydney: Macquarie Graduate School of Management. doi:10.2139/ssrn.798724.

Goldsmith, S., \& Samson, D. (2005). Sustainable development and business success. Reaching beyond the rhetoric to superior performance. A Report of the Australian Business Foundation and the Foundation for Sustainable Economic Development at the University of Melbourne. Retrieved October 23, 2013, from http://www.nswbusinesschamber.com.au/ NSWBCWebsite/media/Policy/Thinking $\% 20$ Business \%20Reports/Older\%20Reports/ Sustainable-Business-Development.pdf.
Hahn, T., \& Scheermesser, M. (2006). Approaches to Corporate Sustainability among German Companies. Corporate Social Responsibility and Environmental Management, 13(3), 150-165. doi:10.1002/csr.100.

Harmon, J., Fairfield, K., Wirtenberg, J., \& Russell, W. (2012). First Annual Survey of New Jersey Business Sustainability. Fairleigh Dickinson University: Institute for Sustainable Enterprise. Retrieved November 15, 2015, from http://view2.fdu.edu/site-downloads/7813.

Hyršlová, J. (2009). Accounting of sustainable company development. Prague: University of Economics and Management. Retrieved August 18, 2013, from http:// www.enviweb.cz/download/ea/ucetnictvi_ udrzitelneho_rozvoje.pdf.

lonescu-Somers, A. (2012). What's stopping your sustainability schemes? You are. Switzerland: International Institute for Management Development. Retrieved December 30, 2014, from http://www.imd.org/ research/challenges/upload/TC023-12_Whats-stopping-your-sustainability-schemes.pdf.

Kocmanová, A., Hřebíček, J., \& Dočekalová, M. (2011). Corporate governance and sustainability. Economics and Management, 16, 543-550. Retrieved January 24, 2015, from http:// www.researchgate.net/profile/Jii_Hebicek/ publication/228461240_CORPORATE GOVERNANCE_AND_SŪSTAINABILITYI links/0912f508a0cdf3dee-1000000.pdf.

Lourenço, I. C., Branco, M. C., Curto, J. D., \& Eugénio, T. (2011). How does the market value corporate sustainability performance? Retrieved October 24, 2014, from http://www. fep.up.pt/conferencias/10seminariogrudis/ Louren\%C3\%A7o,\%20lsabel\%20et\%20al\%20 $\% 20$ How $\% 20$ does $\% 20$ the $\% 20$ market $\% 20$ value $\% 20$ corporate $\% 20$ sustainability $\% 20$ performance\%20\%20 Paper_DJSI_ Grudis2011.pdf.

Nemcová, E. (2012). Sustainable development versus competitiveness of EU industry. Prognostické práce, 4(1), 51-69. Retrieved January 25, 2015, from http://www. prog.sav.sk/subory/pprace/clanok3-PP-1Nemcova.pdf.

EC. The new definition of SMEs. User guide and model declaration. Retrieved March 14, 2013, from http://ec.europa.eu/enterprise/ policies/sme/files/sme_definition/sme_user_ guide_sk.pdf. 


\section{Ekonomika a management}

UN Documents. (1987). Our Common Future, Chapter 2: Towards Sustainable Development. Switzerland: Geneva. Retrieved January 15, 2014, from http://www.undocuments.net/ocf-02.htm.

Porrit, J. (2003). The World in Context: Beyond the Business. Case for Sustainable Development. University of Cambridge. Retrieved October 30, 2014, from http://www.cpsl.cam.ac.uk/Test/ WhatisSustainabilityLeadership/ /media/ Files/Complete \%20publications $\% 20$ for $\% 20$ download/The_World_in_Context.ashx.

Raslanas, S., Stasiukynas, A., \& Krutinis, M. (2012). Some aspects of sustainable real estate development: A case study of Druskinninkai snow arena in Lithuania. E\&M Ekonomice a Management. 15(4), 52-54.

Rusinko, C. A., Pastore, C., Pierce, J., Fleming, R., Frosten, S., \& Cristoffersen, S. (2005). Sustainability as a source of competitive advantage. Retrieved November 24, 2014, from http://www.ntcresearch.org/pdf-rpts/AnRp03/ S03-PH01-A3.pdf.

Setthasakko, W. (2007). Determinants of corporate sustainability: Thai frozen seafood processors. British Food Journal, 109(2), 155168. doi.org/10.1108/00070700710725518.
Shirastava, P., \& Hart, S. (1995). Creating sustainable corporations. Business Strategy and the Environment, 4(3), 154-165. doi:10.1002/bse.3280040307.

prof. Viera Marková, PhD. Matej Bel University in Banská Bystrica Faculty of Economics viera.markova@umb.sk

Ing. Petra Lesníková, PhD. Technical University in Zvolen Faculty of Wood Sciences and Technology Department of Business Economics lesnikova@tuzvo.sk

Ing. Alena Kaščáková, PhD. Matej Bel University in Banská Bystrica Faculty of Economics alena.kascakova@umb.sk

Ing. Miroslava Vinczeová, PhD. Matej Bel University in Banská Bystrica Faculty of Economics miroslava.vinczeova@umb.sk 


\title{
Abstract
}

\section{THE PRESENT STATUS OF SUSTAINABILITY CONCEPT IMPLEMENTATION BY BUSINESSES IN SELECTED INDUSTRIES IN THE SLOVAK REPUBLIC}

\author{
Viera Marková, Petra Lesníková, Alena Kaščáková, Miroslava Vinczeová
}

On a macro level, a concept of sustainable development was first known in context of the larger societal development and the assurance of future generational needs. Nowadays many of individuals, companies, and other organizations are becoming aware of a need of another specific approach to living, manufacturing and doing business. The term of sustainable development has also increasingly been used on a micro level. For a business, these practices imply an effort to incorporate the social and environmental issues into the business model while simultaneously achieving longterm business growth and efficiency. The aim of the paper is, based on the analysis of sustainability concept implementation by businesses in selected industries, to identify the underlying motives and barriers to concept implementation in practice. The motives leading to sustainability concept implementation were found by means of comparison with foreign research. Another objective was to underline the most frequently used tools supporting business sustainability in particular areas and as a whole. By means of a hierarchical cluster analysis we provide a more comprehensive view of businesses' approach to a sustainability concept. Through the objectives of this paper we have formulated six hypotheses. To verify the hypotheses we used the statistical method of analysis. By use of a questionnaire survey, we analyzed 455 businesses belonging to selected industries. The results indicated several options to improve the current state of sustainability implementation which would be beneficial for both businesses as well as the wider environment. The solution for the indicated problems, however, requires not only participation of the business sector but also the interaction of the state.

Key Words: Business sustainability, motives of implementation, hierarchical cluster analysis.

JEL Classification: M14, L20.

DOI: 10.15240/tul/001/2017-3-007 